\title{
Comparative Study on Restaurants' Furniture: Ginkgo and Niazi's Restaurants in Famagusta, Cyprus
}

\author{
Ejeng Ukabi*, Huriye Gurdalli \\ Faculty of Architecture, Near East University, Nicosia/Near East Boulevard, TRNC, 99138, Turkey
}

Received October 25, 2020; Revised December 15, 2020; Accepted January 20, 2021

\section{Cite This Paper in the following Citation Styles}

(a): [1] Ejeng Ukabi, Huriye Gurdalli, "Comparative Study on Restaurants' Furniture: Ginkgo and Niazi's Restaurants in Famagusta, Cyprus," Civil Engineering and Architecture, Vol. 9, No. 1, pp. 23 - 41, 2021. DOI: 10.13189/cea.2021.090103.

(b): Ejeng Ukabi, Huriye Gurdalli (2021). Comparative Study on Restaurants' Furniture: Ginkgo and Niazi's Restaurants in Famagusta, Cyprus. Civil Engineering and Architecture, 9(1), 23 - 41. DOI: 10.13189/cea.2021.090103.

Copyright $@ 2021$ by authors, all rights reserved. Authors agree that this article remains permanently open access under the terms of the Creative Commons Attribution License 4.0 International License

\begin{abstract}
The role of furniture in commercial spaces supports the diversity of human interactions. Beyond the user's importance, furniture also reflects cultures and exerts psychological influences on people at different levels of social stratification. The style tells about a period, and its arrangement with form can contribute to the restaurant's ambiance. Today, restaurants have become an integral part of the urban space's functioning in food servicing provision and in conjunction with other subsidiary functions like Cafe to ease users' taste and intentions. This paper aims to identify the similarities and differences in the furniture used in two restaurants with different construction periods and districts-historical and modern within a city, Ginkgo Restaurant and Niazi's Restaurant in Famagusta-Cyprus. The study will also consider the spatiality of the restaurants and their synthesis with the outdoor space. The paper adopts a case-oriented approach, a thorough physical assessment of the indoor and outdoor spatiality of the restaurants selected. The techniques included field sketches/preparation of measured drawings and making field notes complemented by taking photographs. This comparative furniture analysis highlights public consciousness for tourists, designers, students, and Public-Private Partnership for cities undergoing urban change to pay attention to restaurant spaces as a proponent to sustainable urban health.
\end{abstract}

Keywords Interior elements, Furniture, Restaurant trend, Seating, Spatiality, Ginkgo Restaurant, Niazi's Restaurant

\section{Introduction}

Furniture, as part of interior elements, influences the esthetic of spaces and contributes enormously to users' preference of a concrete space due to satisfaction derived in providing proximity and sensual consumption within a given context [1]. Researchers also estimated that a restaurant space's tangible and intangible environmental elements generate perceptional clues to direct users' preference [2,3]. As a follow-up, restaurants represent social-spatial structures for humans to express themselves [4]. Restaurants are patronized frequently by festivity, home-away dining, break time at work/schools, and tourism/hospitality activities. The availability of restaurants in Famagusta with the internationalization of tertiary education and tourism development is another cultural tendency that constitutes urban drivers. The ambiance of the restaurant's spatial layering for which furniture plays a key role represents sustainable input for the design and operation of foodservice and hospitality outfits.

Additionally, the endemic Mediaeval textures of Famagusta represent an open-door exhibit site endowed with historical ruins and monuments of Cyprus heritage, providing another richness of the city, forming a primary source of attraction. Perhaps, it is time to take up the study to compare the restaurants' furniture of Ginkgo and Niazi's restaurant as we watch the changing demographics, urban life, and morphology of Famagusta. The literature on the works completed on furniture comparative is few, tailored to user patterns [5]. The principal aim of this paper 
focuses on examining the similarities and distinctiveness of restaurant furniture but will fulfill the following objectives:

i). How do spatial restrictions influence the ambiance of restaurant architecture and operations?

ii). How does the relationship between indoor space and outdoor space affect diners' preference for a restaurant?

\section{Materials and Methods}

The general research methodology adopted for this comparative study on restaurant furniture is qualitative, which is case-oriented. It entailed two phases. The first stage involved a literature review, which included a search on for different scholarly works (very limited sources about the focus), opening up the process to embrace interior designers, hospitality, leisure bloggers, magazines, and travel journalists who researched about interior elements and ambiance in restaurants-followed by a physical assessment of the two cases: Ginkgo Restaurant and Niazi's Restaurant, that comprised field studies for three consecutive visit to each, preparing sketches, taking measurements, notes and taking photographs of the current physical conditions of the buildings and observing diners behavior within the premises. Within the context considered, maps and old pictures of the restaurants are review to appreciate the change from the inception of operation, from the restaurants' web page and enlargements/portraits displayed on the walls. A conversation with the managers of the cases studied provided the verification of background narratives retrieved from the online sources and tourism/travel promoters of Famagusta Tourism Office at the Old City Southern Gate entrance.

The second phase is analysis, which included studio reviews to organize the measured drawings (site layout, plan, and section), which constituted part of the data collection technique to conduct the comparative analysis - engaging four (4) spatiality indicators: site criteria-district, environment, building type, the period of construction, and space composition (area, capacity, floor/wall material texture, and headroom) to generate the historical data of the cases, followed by furniture style, seating arrangement/pattern, furniture type, and other interior elements to unveil the distinctiveness of the furniture. The effective use of inventory forms, tables, charts, and technical descriptions would be harness to extract and present the results. Observation is engaged through the entire process to inform the interpretations of the results and discussions for a conclusion, Figure 1.

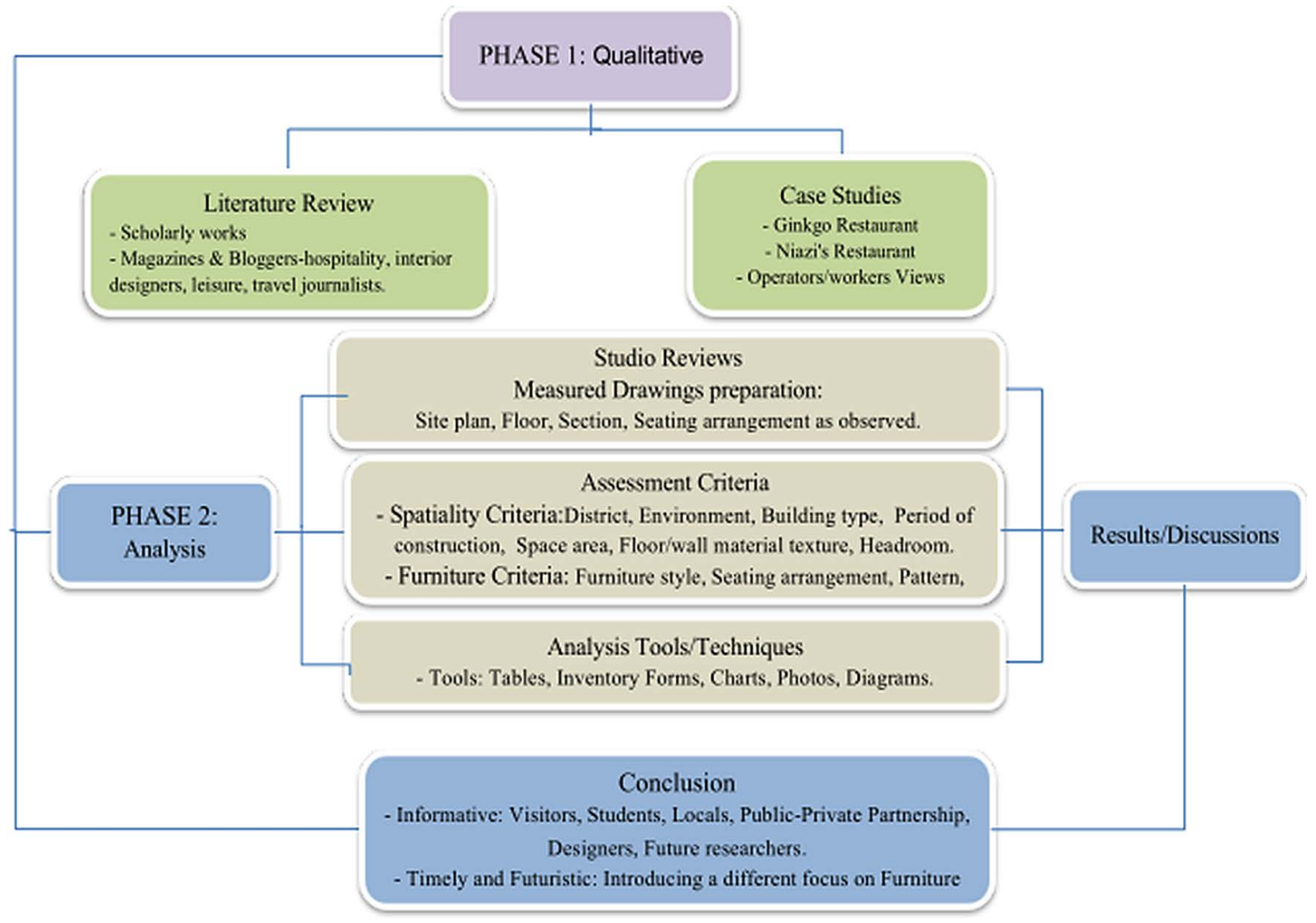

Figure 1. Summary of Comparative Study Methodology 


\subsection{The Trends in Restaurant}

The study conducted on measuring tangible quality in the food-service industry by [6] reveals restaurants' evolving nature due to changes in customers' lifestyles and many competitors' availability at different strata. It is also evidence that restaurants are the meeting place where food and culture converge [7]. A recent work that focused on analyzing 19 prominent gastronomy facilities highlighted the industry's category into restaurants, cafeterias, cafes, and clubs/bars. This grouping correlates and indicates the diversity and essence of taste and ambiance in the food industry in different cultural settings.

In ancient civilizations, a restaurant's need arose due to the non-inclusion of kitchens in the constructed residential houses and associated with the "thermopolia" [8]. It was a public place for serving warm food and beverages [9]. Although some authors trace the restaurant's starting to the French Revolution of 1789, a recent publication argues that urban restaurant culture existed before the restaurants in Paris as supported by the Southern Sung Dynasty [10]. In that trend example of ancient restaurants is "Sobrino de Botin," established in 1725 in Madrid, Spain, and is functioning to date [11].

In that trajectory, the study conducted on measuring tangible quality in the food industry retrospected that during and after World War II in Britain, the introduction of meal service through British restaurants adopted the cafeteria approach [12]. Their program further included functions complemented with other food provision schemes like community feeding centers, school, and workers canteens cooking depots, emergency meals centers, rest centers, and mobile canteens. That research explained the essence of restaurants in war times and its assistance to lessen domestic labor on women during childbearing in 1900-2000. However, from the literature surveyed, it is time to simplify the restaurant industry's fundamental shifts into three categories, as shown in Table 1. Based on the data provided by two research types, which concentrated on restaurants' rise and its future $[13,14]$.

Table 1. Shifts in restaurant industry

\begin{tabular}{|c|c|c|c|}
\hline & $\begin{array}{l}\text { Approach of shift } \\
\text { and Period }\end{array}$ & Target & Categories \\
\hline 1 & $\begin{array}{c}\text { Household } \\
\text { Approach-Before } \\
\text { 18th Century }\end{array}$ & $\begin{array}{l}\text { Hospitality } \\
\text { focused }\end{array}$ & $\begin{array}{l}\text { - Meals provision for } \\
\text { full nutrition. } \\
\text { - Cultural interest. } \\
\text { - Sensory engaging. } \\
\text { - Participatory. } \\
\text { - Parallel. }\end{array}$ \\
\hline 2 & $\begin{array}{c}\text { Corporate } \\
\text { Approach-After } \\
\text { 18th Century }\end{array}$ & $\begin{array}{c}\text { Wealth } \\
\text { maximization }\end{array}$ & $\begin{array}{l}\text { - Price signaling. } \\
\text { - Competitive. }\end{array}$ \\
\hline 3 & $\begin{array}{c}\text { Smart } \\
\text { Approach-Toward } \\
\text { 20th Century } \\
\text { upward }\end{array}$ & $\begin{array}{l}\text { Technology } \\
\text { driven for } \\
\text { new culture }\end{array}$ & $\begin{array}{l}\text { - Speed of service. } \\
\text { - Space constraint. } \\
\text { - conscious. } \\
\text { - Timeless. } \\
\text { - No context biased. } \\
\text { - More profit. }\end{array}$ \\
\hline
\end{tabular}

\subsection{Classification of Restaurants}

A critical look at the background provided shows that restaurants exist in various forms depending on the parameters selected for their operational categorization. Based on this concept, the research on classifying Canada's food and beverage service businesses will be considered for the grouping [15], especially as nomenclatures used shows a widely encompassing character of other types of restaurants listed by authors in Travel Magazines. The two generic levels of restaurants are commercial foodservice restaurants and non-commercial foodservice restaurants. In countries where the restaurant business is trending, the two major classes relate to the ratio $4: 1$. Commercial foodservice restaurants operate primarily in the food and beverage business. In contrast, non-commercial foodservice restaurants refer to facilities where food and beverages served customers means a secondary service but not the core business. Table 2 provides information about the classification in a compressed manner for better understanding due to the sub-groups' complex nature.

Table 2. Restaurant categorization

\begin{tabular}{|c|c|c|}
\hline & Class & Types \\
\hline 1 & $\begin{array}{l}\text { Commercial } \\
\text { Food-service }\end{array}$ & $\begin{array}{c}\text { Quick-service, Full-service, Cafe, } \\
\text { Catering. }\end{array}$ \\
\hline 2 & $\begin{array}{l}\text { Non-commercial } \\
\text { Food-service }\end{array}$ & $\begin{array}{l}\text { - Institutional: } \\
\text { Hospitals, schools, Prisons, Corporate } \\
\text { staff cafeterias, Cruise ships, Airports } \\
\text { and transportation terminals. } \\
\text { - Accommodation foodservice: } \\
\text { Hotel restaurants and bar, Room service } \\
\text { and Self-serve dining operations. } \\
\text { - Vending and automated foodservice. }\end{array}$ \\
\hline
\end{tabular}

\subsection{Interior Elements in Restaurants}

Restaurants square-up on parameters like location, prices, promotions and service, and others but the interior elements evoke customers psychologically. How? It influences order mode, duration of stay, tendency to return to, and make referrals. At the apex of the foodservice industry and hospitality, interior impression directly connects and explains its brand. Based on the essay of The Restaurant Times, the importance of restaurant interior elements are compressed thus:

- It is a branding and marketing strategy.

- Aid in defining the restaurant idea in an Instagramable manner

- Good looking interiors feature the role of a coded sales duty.

As purported in the essays of $[16,17,18]$, restaurants' primary interior elements include architecture, lighting, seating, colors, smell, surfaces texture, acoustics, and temperature. However, this study emphasized indoor/outdoor space and furniture delineation. The customer constitutes the apex for design concept 
formation and consideration from the review of restaurants' interior elements essays explored. The study deduced three terminologies summarizing the practical application of ambiance produce attraction, experientiality, and attachment as possible pragmatic considerations for restaurants' architecture and operation. In correlating these design requirements with furniture design, [19] suggested that linking social identity difference, experience, and change (time specificity) would constitute a vital balance for furniture production.

\subsubsection{Architecture and Seating in Restaurant}

The restaurant's spatial composition and layout are the platforms upon which the users and restaurant workers interact to gain satisfaction. The process requires conscious planning and use of anthropometric spatial standards [20] and modular coordination principles [21] to avoid conflict between person to person, likewise person to objects to fit ergonomic guidelines. The application of personal space in a public context through engaging space equilibrium weight for eliminating space phobia remains instrumental, according to [22] linked to concepts of proximity and territoriality [23]. Arguably, "[16]" from the perspective of working on hospitality projects in Canada contributed that careful handling of the "social quotient" of the design concept with the scale of the restaurant space will, in the long run, elevate space ambiance into a sense of place as a result of spatial experience. This sensitivity passively creates customers' attachment to the restaurant as a derivative for satisfaction to handle other life affairs, not just-food [24]. Recent work on criteria ranking for innovative restaurant design by [25] projected performance, creativity, aesthetics, and eco-friendliness as primary factors for future design and operation. At the level of the design industry, the four criteria are notable. These keywords define a pragmatic architecture and environmental resilience. However, each of the terms represents a dynamic design terminology, mutually interwoven from the architectural design sense. That is, a selection of one would lead to connecting others.

Furthermore, in the development of design concepts, they are specific design requirements that are not independent but depend on the combination of different design elements and design principles. The implementation of these requirements is case-oriented and context-sensitive, forming the application distinction from other design areas that assume global context. Our take on this is that even though the four criteria are analyzed quantitatively on one side, but their practical application is another problematic aspect demanding creativity and innovation. Based on these facts, there is relativity between restaurants within a city with different environmental sensitivities. It also explains the relationship between culture and space that designers and operators must not undermine when creating or maintaining dining spaces.

In this regard, the specifications given in reference books and handbooks of designing show that minimum space for seating depends on the type of seating and the number of persons per table [26]. The seating details sourced from "The Architects' Handbook" are simplified diagrammatically in Figure 2 for a smart understanding by using visual shape naming together with the technical data. Ranging from two persons to eight opened for increment based on selecting movable or flexible seating combinations, and the letter "P" in the diagram denotes the number of persons.

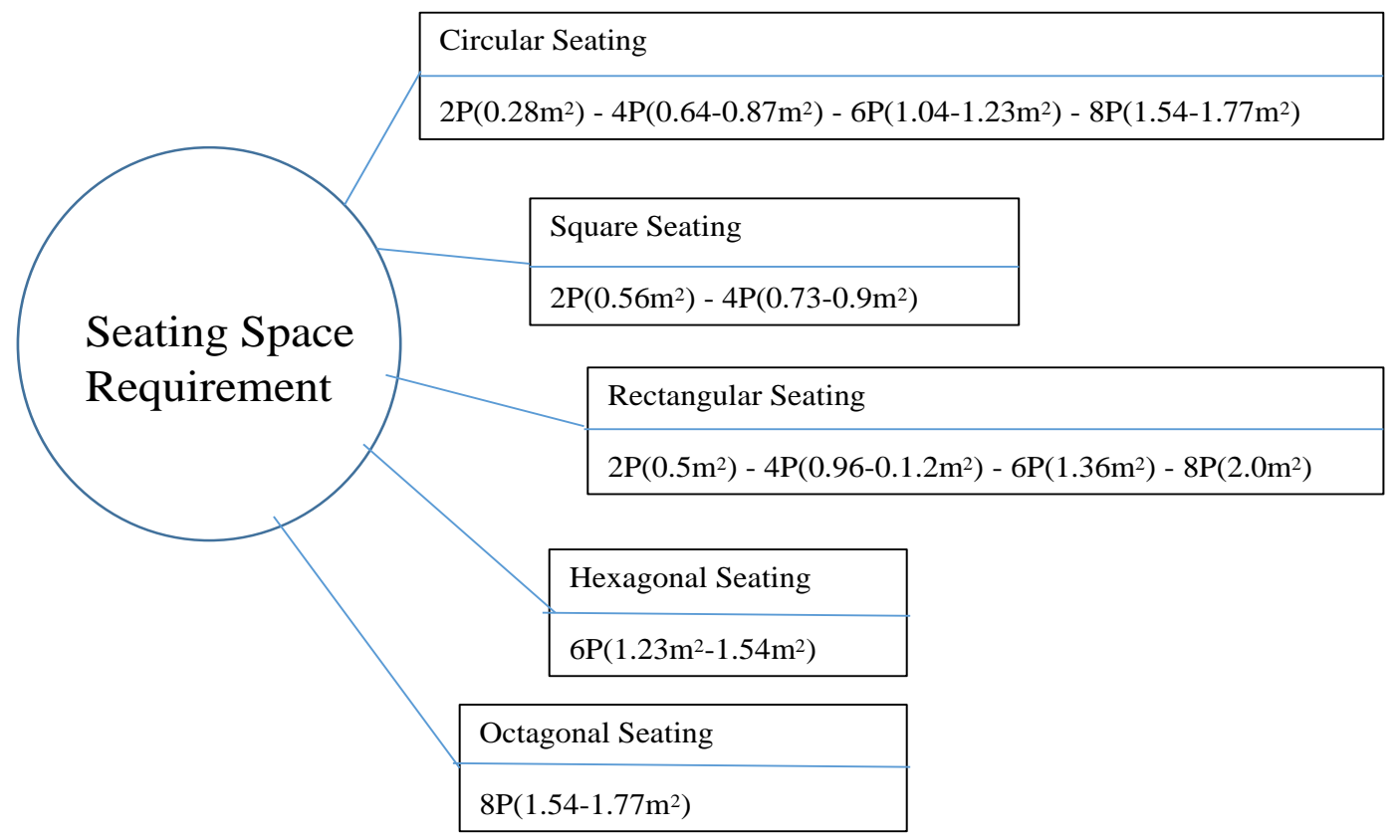

Figure 2. Seating Space Specification for Restaurants 
The diagram shows that hexagonal and octagonal seating arrangements offer high index restrictions on space's dynamic layering because of the difficulty of mutilating their form. However, circular, rectangular, and square seating provide a high index of flexibility. Prescriptively, designers find out that a careful combination of the different seating organization types will create a decorative and sensual atmosphere.

The necessity to have seats as a restaurant's functional component is a familiar semantics from design and use. Nevertheless, its influence on customers' experiential state and story inadequately captured in design arguments. The two feelings expression that emerges fall into beautiful seats with no or light seat pad invites but does not keep the customer for a longer duration-this kind of perceptual clue interplays in Quick Service Restaurants like McDonald. On the contrarily, comfortable seats with plump sofas and cushions are both welcoming and relaxing. It is thereby promoting customers to stay longer and order more like in Fine Dining and Cafe.

\subsection{Users' Sensitivity to Furniture and other Interior Elements in Restaurant}

The emotional aspect of Alvar Aalto's designs of architecture and furniture combines intuition and scientific skills to communicate the importance of humans' attachment to furniture in a space. He further explains how the user's taste to function dynamically will influence furniture use, even though the skeletal body structure is constant [27]. Today, research focused on the esthetic dimension of space, not just its usability [28], has become vital in exploring user preferences for gainful works of architecture and design. Interestingly, the essay on the social-physiological indicators that satisfy eating experience included perception, emotion, customer's behavior, and the presence of their eating companions [29]. Supportively, the work on "User preference of interior design elements in hotel lobby spaces" [30] shows that access to daylight/views is the most crucial element. Seating type/arrangement is the second most important; the lobby's scale scored the third position while materials used in the space were the least important element.

Restaurant spaces possess similar characteristics because of their mutual relationship with hotels and the hospitality industry. Applying implies that restaurant spaces with large windows will provide users with an appealing, comfortable, and active engagement with the external surroundings than those with small or no windows. It also indicates that large space restaurants will be more inviting, celebrating, and boosting users' morale than small space ones. Another essential view is that soft materials are preferable to hard materials due to their properties to induce warmth, relaxation, and homey on the users while the latter inflicts stressful conditions.

On the issue of seating arrangements, researchers opined that seats arranged perpendicularly to one another encourage significant interaction for a companion than in the opposite direction due to other people's presence in the space [31]. While in-group members, opposite seating enhances lively conversation [32]. The need for maintaining personal space in public settings is also applicable in restaurant seating arrangements to ensure privacy and safety [33]. Perhaps for the arrangement of tables/seats in a restaurant space, anchored tables are preferable because of their closeness to building elements like walls, columns, and fenestration than isolated or unanchored tables [34]. This kind of arrangement works for all types of occasions despite the cultural differences of users. The formation of anchored spots supports the user's behavioral tendency for territoriality within the restaurant space's layering as a spatial experience. The former results in more time spent and higher spending in the restaurant environment [35].

\subsection{Famagusta-Cyprus as Study Context}

The Island of Cyprus has gone through a cultural trajectory of historical civilizations [36]. As such, Famagusta is a subset in that social-cultural and political trend, especially as one of the principal harbors which have survived from historical times. The journey through successive civilizations from history to the present is a memorial story that has turned the city into an emblem of cultural diversity. The city shows the remains of the various cultural influences, which is not limited to the socio-economic and political life [37]. Our findings show that the frequent patronage of restaurants by Turkish Cypriots is a lifestyle. Apart from the ancient evolution of the settlement, which no document or archaeological findings have analyzed, the following periods have the corresponding authorities linked as their identities within the City of Famagusta: 648-1192 AD - Known as the early periods (Assyrians, Egyptians, Persians, Romans, Arabs, and Knights of Templar); the making of the foundation of the city; 1192-1489 - Lusignan Period; 1489-1571 - Venetian Period; 1571-1878 - Ottoman Period; 1878-1960 - British Period; 1960-1974 - Republic of Cyprus Period; 1974-1983 - Turkish Federated State of Cyprus; 1983- till date - Turkish Republic of Northern Cyprus [38]. 


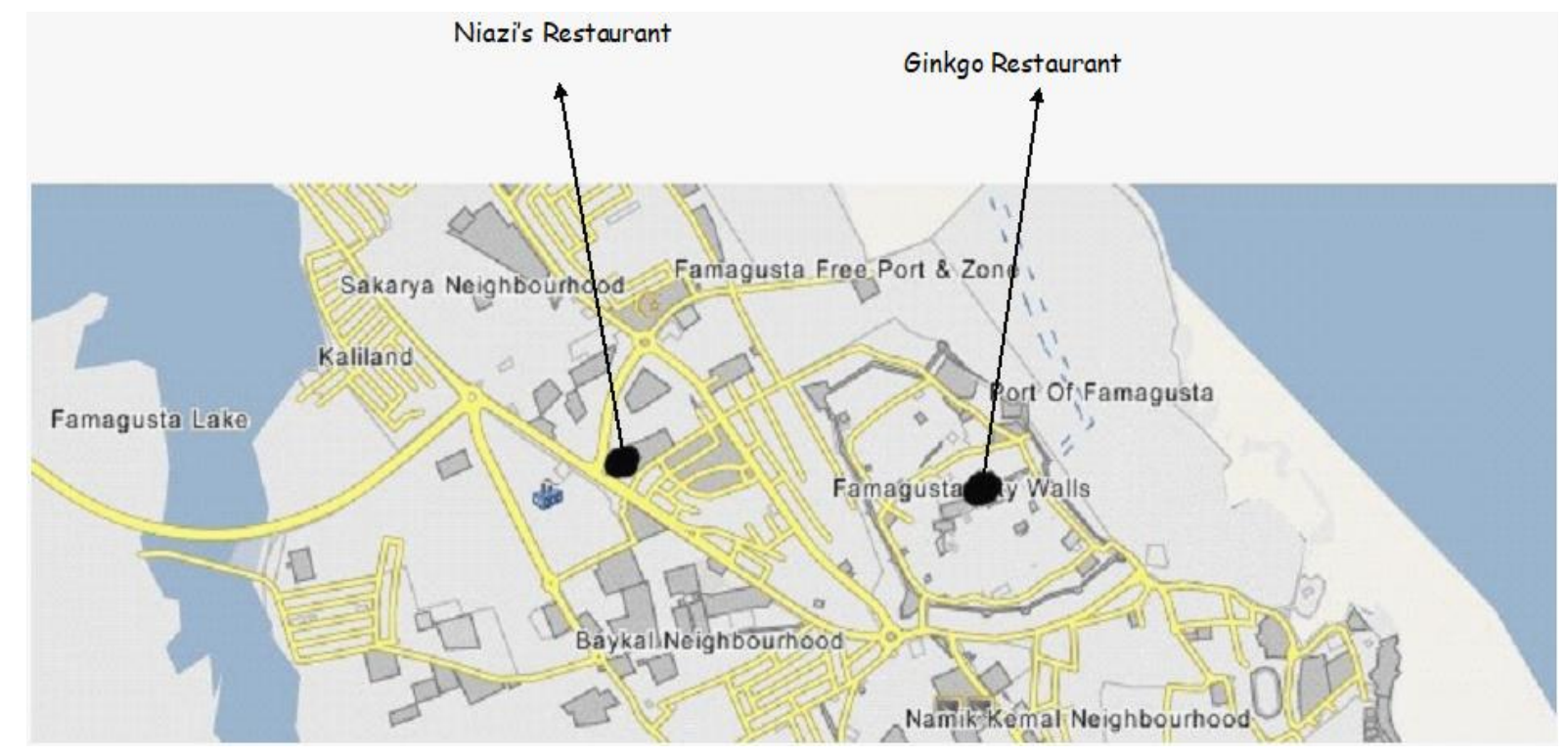

Figure 3. Map of Famagusta spotting study location from Wikimapia.org/8215854

The establishment of Eastern Mediterranean University as the first university in Famagusta and other new ones like Kibris Ada Kent University and Istanbul Technical University constitutes Famagusta's urban development strategy. It requires setting-up more restaurants. The two restaurants Ginkgo (case 1) and Niazi's (case 2), selected as case studies, are uniquely located. Ginkgo Restaurant is situated in the Old City of Famagusta, forming part of the historic urban texture of Namik Kemal Square, and Niazi's Restaurant within the district of Dumlupinar forms part of the modern urban tissue Figure 3. The cases represent a microcosm of a more extensive study that will encompass the three historical cities (Famagusta, Nicosia, and Girne) of North Cyprus under a common theme: 'Furniture and Culture.' The selection mapped for a restaurant that still has the cultural signs and symbols of past civilizations of Cyprus to ascertain the distinctiveness of furniture used in old and new which enabled the definition of the criteria mentioned in the methodology.

\subsection{Results}

The evaluation of the spatial composition of a Korean Traditional House used for Korean restaurants adopted five criteria [39]. Their research used the roof, floor, wall, style, and design philosophy as the criteria analysis model. Based on this typology, our work analyzes Ginkgo and Niazi's restaurants using the order-case description, floor, wall, roof, architectural style, and design philosophy.

\subsubsection{Ginkgo Restaurant}

Ginkgo Restaurant building construction period firstly falls in the Lusignan Period (1192-1489) as part of the Bishop's complex and annex to St. Nicholas Cathedral, the most outstanding Landmark around Namik Kemal Square in the Old City of Famagusta, Cyprus. The Venetians (1489-1571) inherited these structures, made renovations on the surviving buildings of the Lusignan occupation, and synergized them into symbols of the previous occupations' and introduce annexes that portray their cultural dominance for the hosting of civic and public rituals [40]. The Ottoman Empire's seizure of Famagusta was in the period (1571-1878), [41]. The Ottoman administration made additions to the Religious House and renamed Famagusta Madrese and function as a school for Islamic teachings [42]. The renovations made by the Ottoman Empire on the surrounding architecture of the square focus on lining with the conversion of St. Nicholas Cathedral (Church) to the Lala Mustapha Pasha Mosque in 1735. The Madrese, now reuse for Ginkgo Restaurant since 2003, respected as the historical heritage of past civilizations within the historical core of Famagusta and Cyprus, symbolizes diverse cultural layering and identities.

The Ginkgo Restaurant (Case 1) represents three cultural influences. That is the Lusignan Period, Venetian Period, and Ottoman Period in Famagusta. The dome section's insertion organically organized represents an excellent example of integrating three architectural periods in history with their ideologies. That is, Greek Architecture, Roman Architecture, and Byzantine/Ottoman Architecture, forming the grandeur of Medievalism of the time. The operator of Ginkgo Restaurant, having this knowledge, named the restaurant both conceptually and symbolically to the name of a historic tree known as "Ginkgo Tree," which unites the philosophy of the opposite: Light and dark; male and female [43]. Contextually, the Cafe is operated on the Lusignan/Venetian part while the Fine Dining is on the Ottoman section but linked and serviced together. It 
operates as a commercial food-service restaurant under the full-service sub-class following the groupings identified in the literature (see "Table 2"). Attempts were made to introduce the menu of those periods but aborted due to customers' conservative response to many international cuisines [44], perhaps owing to the bulk of diners being tourists. The photographs of the Ginkgo restaurant shown in Figure 4-8.

The floor plan of Ginkgo Restaurant is typically designed for two main compartments (Cafe and Fine Dining) and raised from the natural ground at a level of $1.05 \mathrm{~m}$. Specifically, showing a total area of approximately 174 square meters, a seating capacity of 61 persons internally and 42 persons on the outside. The Cafe area is L-shaped with brick-like creamy colored marble floor tiles, while the Fine Dining section is a square shape with diagonal laid creamy rough-edge marble tiles. The entire wall's construction in brownish stones as a dominant local material regional to Cyprus from history and massive. The walls of the Cafe are approximately $0.9 \mathrm{~m}$ wide with high-level Wooden Tracery Gothic windows to a width of $0.6 \mathrm{~m}$ and with two glazed door entrances, one to the western elevation and the other to the north elevation. The walls of the Fine Dining are $0.45 \mathrm{~m}$ in width with a living room-like window sill level finished in rectangular wooden glazed panes casement windows with a width of $1.0 \mathrm{~m}$ and with a decorated marble entrance-way linking the Fine Dining with the Cafe. The Fine Dining on the east wall shows a central recess for Fire Place with an open-able glazed casing and a wooden door leading to the conveniences. The Cafe walls with a headroom measuring $4.8 \mathrm{~m}$ high beautifully stabilize by constructed vaults and a flat stone roof, while the Fine Dining stone dome links the walls together in an adoring feeling of awe and function as the roof.

Ginkgo Restaurant is a combination of two architectural styles in history: Gothic and Byzantine styles, which are the critical features of Medieval Architecture in Europe and other contexts under European civilization controls.

The era's philosophy was on the dominance of vaults, domes, pointed arches, and columnar as displayed on religious buildings and military architecture. The small window openings and the walls' solidity explain the traditional building techniques with climatic understanding but restrict visual connection between the inside and outside spaces. They constitute a weakness for interaction with the surrounding. Invariably, providing the scenario for which users prefer the outdoor seating than the inside except when weather conditions are harsh.
White and blue colored umbrellas are mounted on the outdoor space to provide shade for users.

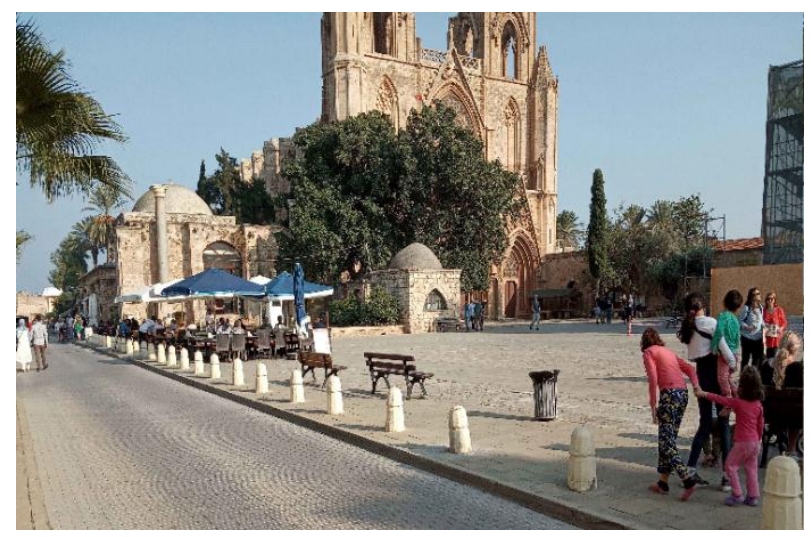

Figure 4. Ginkgo Restaurant with the outdoor seating area at present

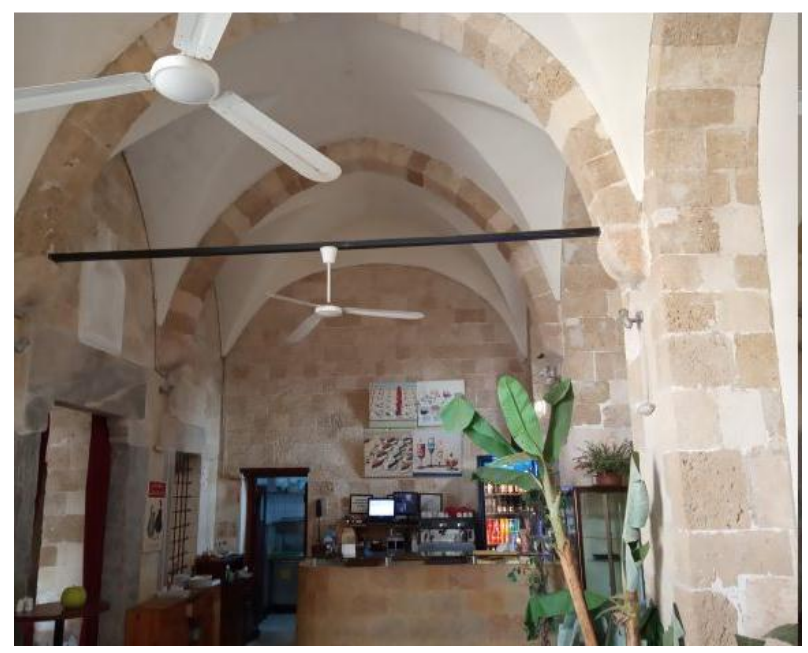

Figure 5. Ginkgo Restaurant Interior of Cafe/cashier point

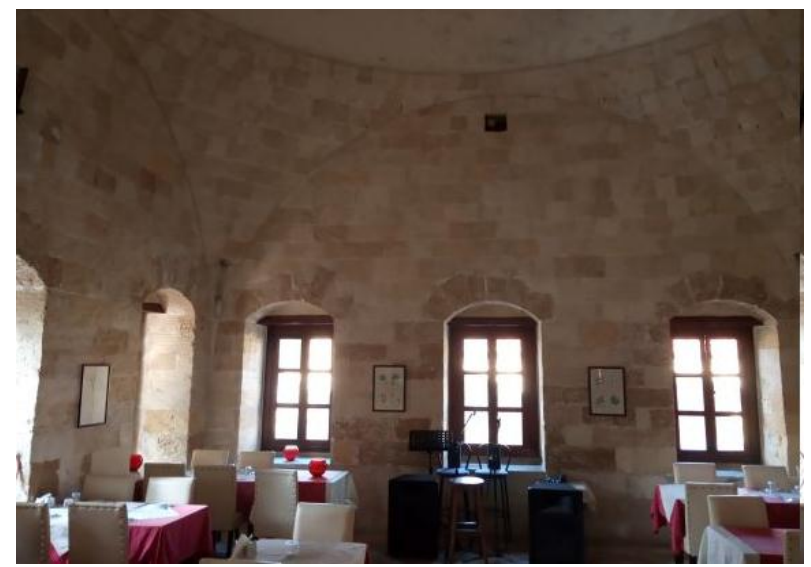

Figure 6. Ginkgo Restaurant Interior of Fine Dining 


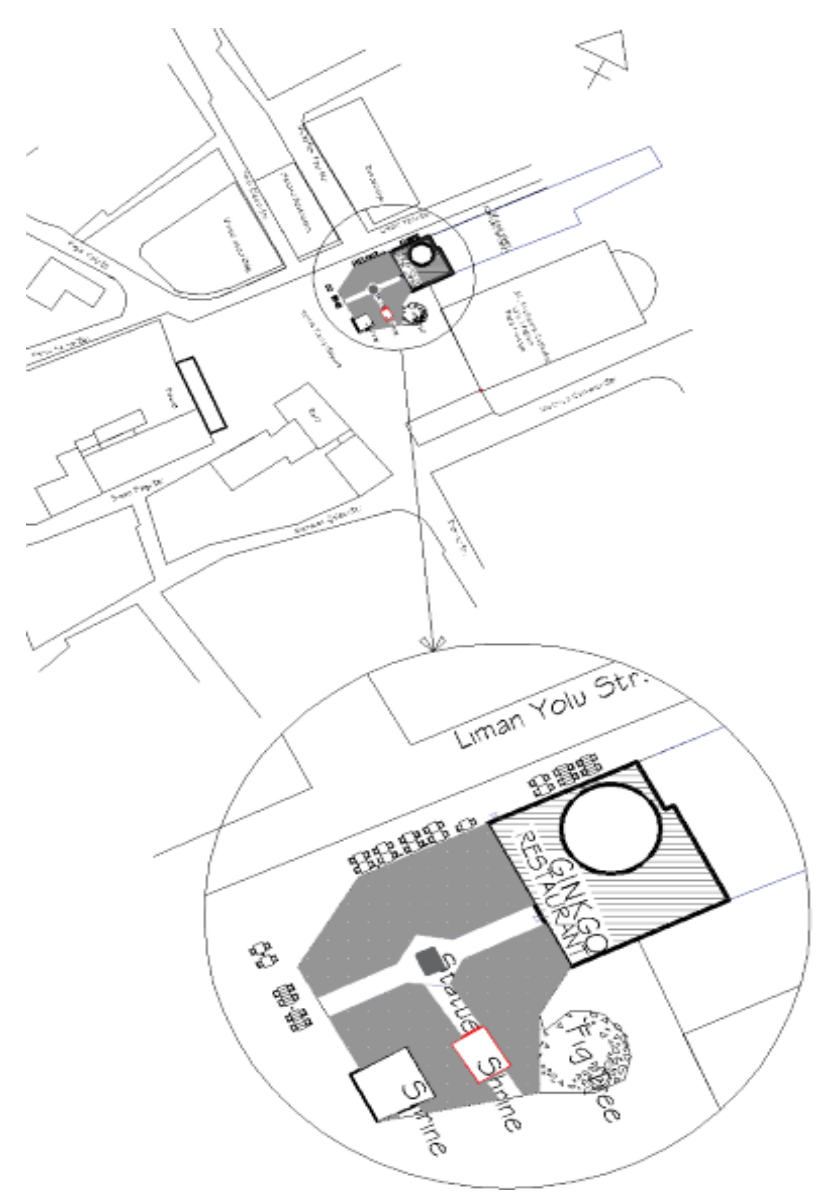

Figure 7. Site plan and outdoor seating of Ginkgo Restaurant
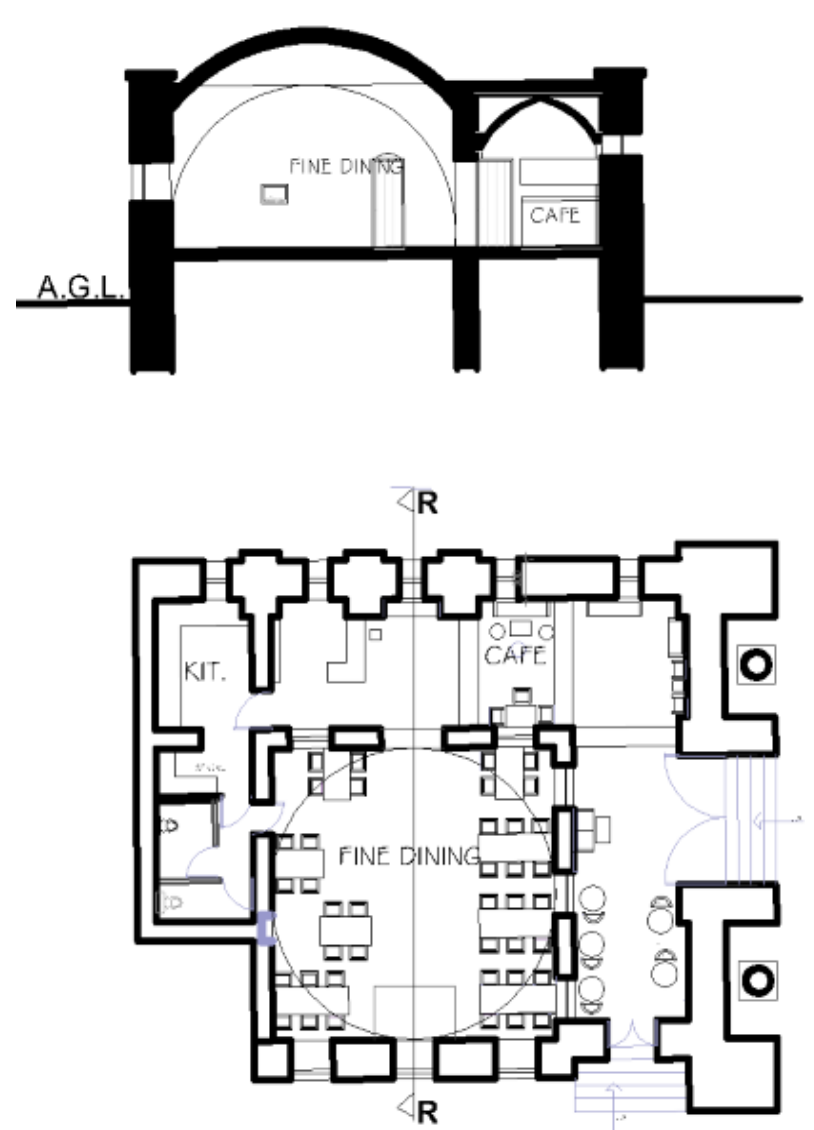

Figure 8. Floor plan, interior furniture arrangement and Section of Ginkgo Restaurant 
2.6.2. Furniture Identified in Ginkgo Restaurant

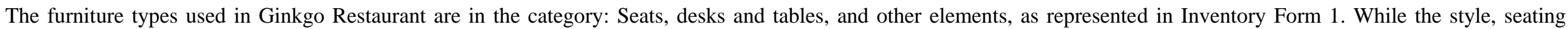
arrangement, and seating pattern are analyzed in Table 3.

Inventory Form 1. Ginkgo Restaurant Furniture Types

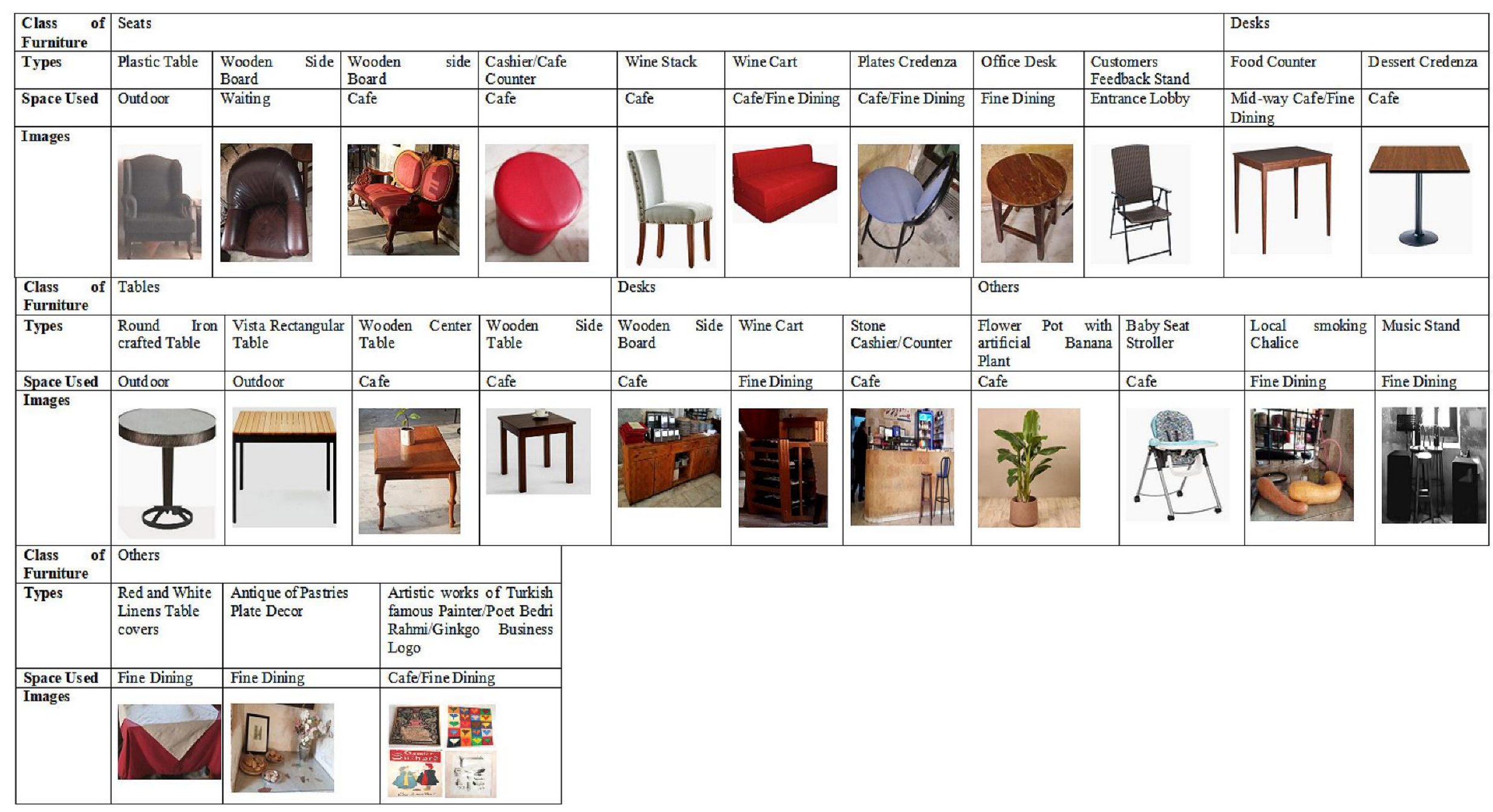


Table 3. Ginkgo Restaurant furniture summary results

\begin{tabular}{|c|c|c|c|}
\hline Parameter & Fine Dining & Cafe & Outdoor \\
\hline $\begin{array}{c}\text { Furniture } \\
\text { Style }\end{array}$ & \multicolumn{3}{|c|}{ Medieval, French, Ottoman, Arts and crafts. } \\
\hline $\begin{array}{c}\text { Seating } \\
\text { Arrangement }\end{array}$ & $\begin{array}{l}\text { - } 4 \text { sets of } 4 \text { seats to a } \\
\text { rectangular table. } \\
\text { - } 4 \text { sets of } 6 \text { seats to two } \\
\text { rectangular movable tables. }\end{array}$ & $\begin{array}{l}\text { - } 2 \text { independent bar stools. } \\
\text { - } 5 \text { sets of } 1 \text { seat to a circular table. } \\
\text { - } 1 \text { set of } 4 \text { seats to a rectangular table. } \\
\text { - } 1 \text { boot seat with } 2 \text { round seats to a square center table. } \\
\text { - } 4 \text { boot seats without connection to a table. }\end{array}$ & $\begin{array}{l}\text { - } 9 \text { sets of } 4 \text { seats to } \\
\text { rectangular table. } \\
\text { - } 3 \text { sets of } 2 \text { seats to square } \\
\text { table. }\end{array}$ \\
\hline $\begin{array}{l}\text { Seating } \\
\text { Pattern }\end{array}$ & Perpendicular & Anchored (L-shape that is edge oriented). & L-shape \\
\hline
\end{tabular}

\subsubsection{Niazi's Restaurant}

Niazi's restaurant is a Cyprus based restaurant that started in 1949 in Limassol. It started operation from a mini storage building used for a market and a small restaurant to service British soldiers and their families [45]. The restaurant began making Kebab (known as the inventor of "Full Kebab") for the soldiers and Greek Cypriots. With large customers' challenges, the business expanded, leading to establishing a modern one in 1967 in the same state. After a few months of opening, the restaurant suspended operations due to the island's 1974 dividing event. The restaurant moved to Kyrenia in the Northern part of Cyprus and introduced the full Kebab to Turkish customers [46]. Today, Kebab has become a cultural food and part of the restaurants and cafes menu for both Greek Cypriots and Turkish Cypriots. Presently, Niazi's Restaurant has grown with six branches in three cities (Kyrenia, Nicosia, and Famagusta) of Northern Cyprus. Case 2 focused on the Famagusta branch, which commences operation in 2013 with the traditional cuisines of full Kebab, charcoal grill meals, and continental dishes. The services offered are three-fold: Full dining, Cafe, and Home delivery service. The photographs of Niazi's are shown in Figure 9-14.

The floor shows a large rectangular shape open floor spatial arrangement with Fine Dining, a transition waiting area, and the Cafe and internal columns cased with coffee feel wooden panels. The total floor area is approximately 276 square meters and has 104 persons on the inside and 60 persons on the outdoor. The whole floor finished with parquet in a dark brown coffee-like color. The walls of width $0.225 \mathrm{~m}$ constructed as a frame showing the positioning of Reinforced concrete (Rc) columns links with Rc beams at a headroom of $3.3 \mathrm{~m}$ high. The fenestration portions on the south, east and west walls are completely glazed in vertical panels, couple with Piano hinges to function as folding doors and transparent skin that actively and visually connect the inside with the outside environment. The south wall glazed door is treated as the main entrance and directly linked with the outdoor seating and children's play area. The second glazed door situates on the west wall, which connects with the car parking area and an external ramp to aid physically disadvantaged people. The north wall shows a door to conveniences, a recessed indoor grilled area within the
Food Canter, and door to the Kitchen, and a straight flight stair leading to the central store treated as a forced mezzanine floor.

The roof is an Rc deck at a structural headroom clearance of $4.5 \mathrm{~m}$ with an internally suspended ceiling at $3.6 \mathrm{~m}$ height. The recessed portions of the ceiling area are finished in white gypsum boards and dark brown wooden panels installed intermittently. Central air-conditioning units and Chandelier lights hung at strategic points. The character of Niazi's Restaurant is a modern style. The modular spatial articulation shown stands pragmatically crafted on the principles of straight lines, elaborates use of eco-materials, large glass panels that point to modern architecture philosophy. The open floor quality combines with the curtain walling to create a soft feel of openness since the building's skin is transparent and accessible with the outdoor space. The outdoor seating is configured with red-colored umbrellas mounted as shade around the seating set-up.

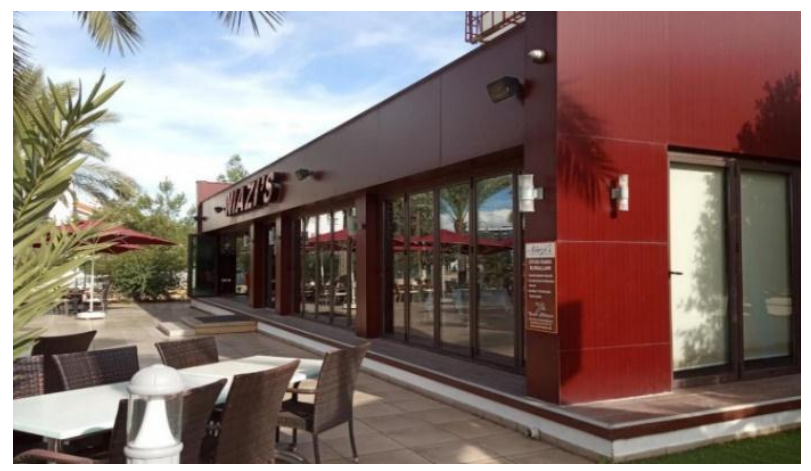

Figure 9. Main Exterior view of Niazi's Restaurant

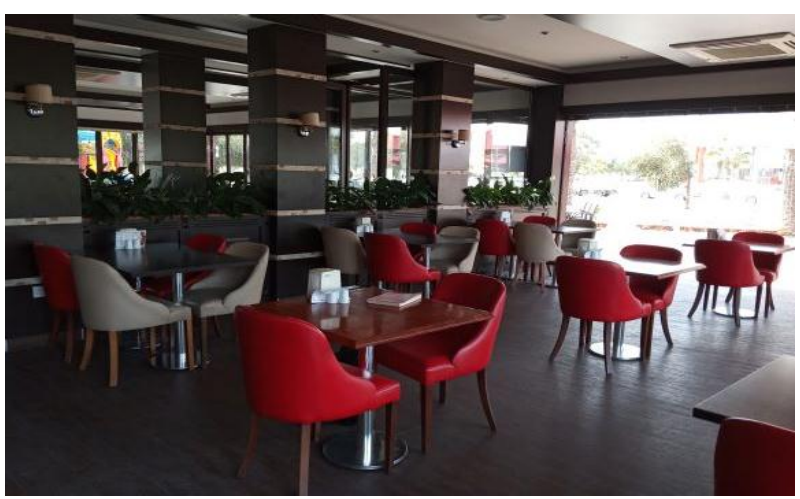

Figure 10. Niazi's Restaurant Interior of Cafe and Quick Service 


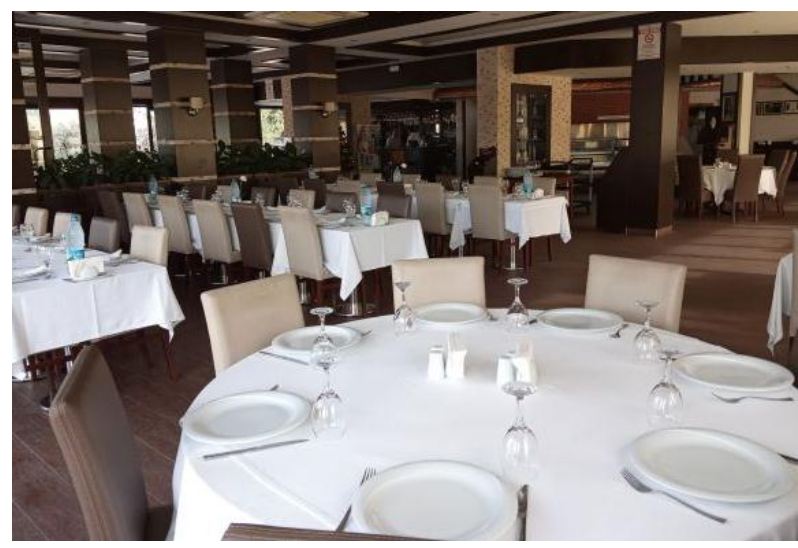

Figure 11. Niazi's Restaurant Interiors of Fine Dining

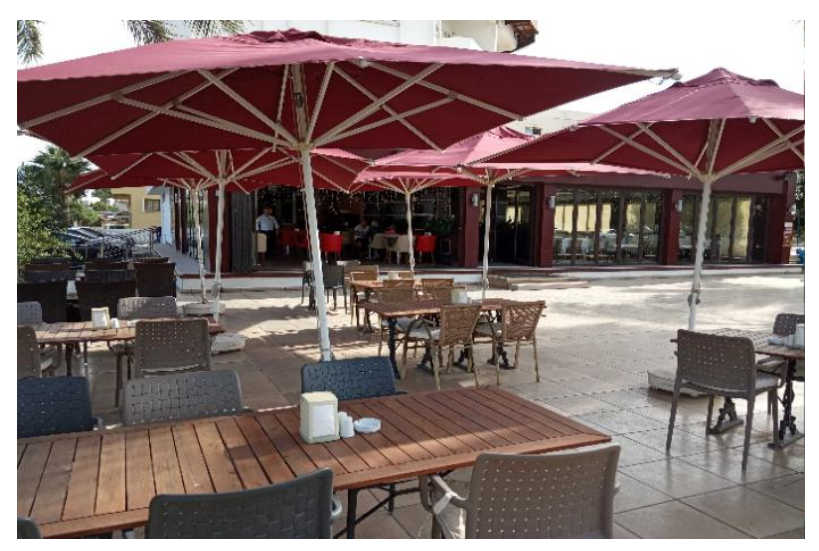

Figure 12. Niazi's Restaurant outdoor area as an extension of the Cafe

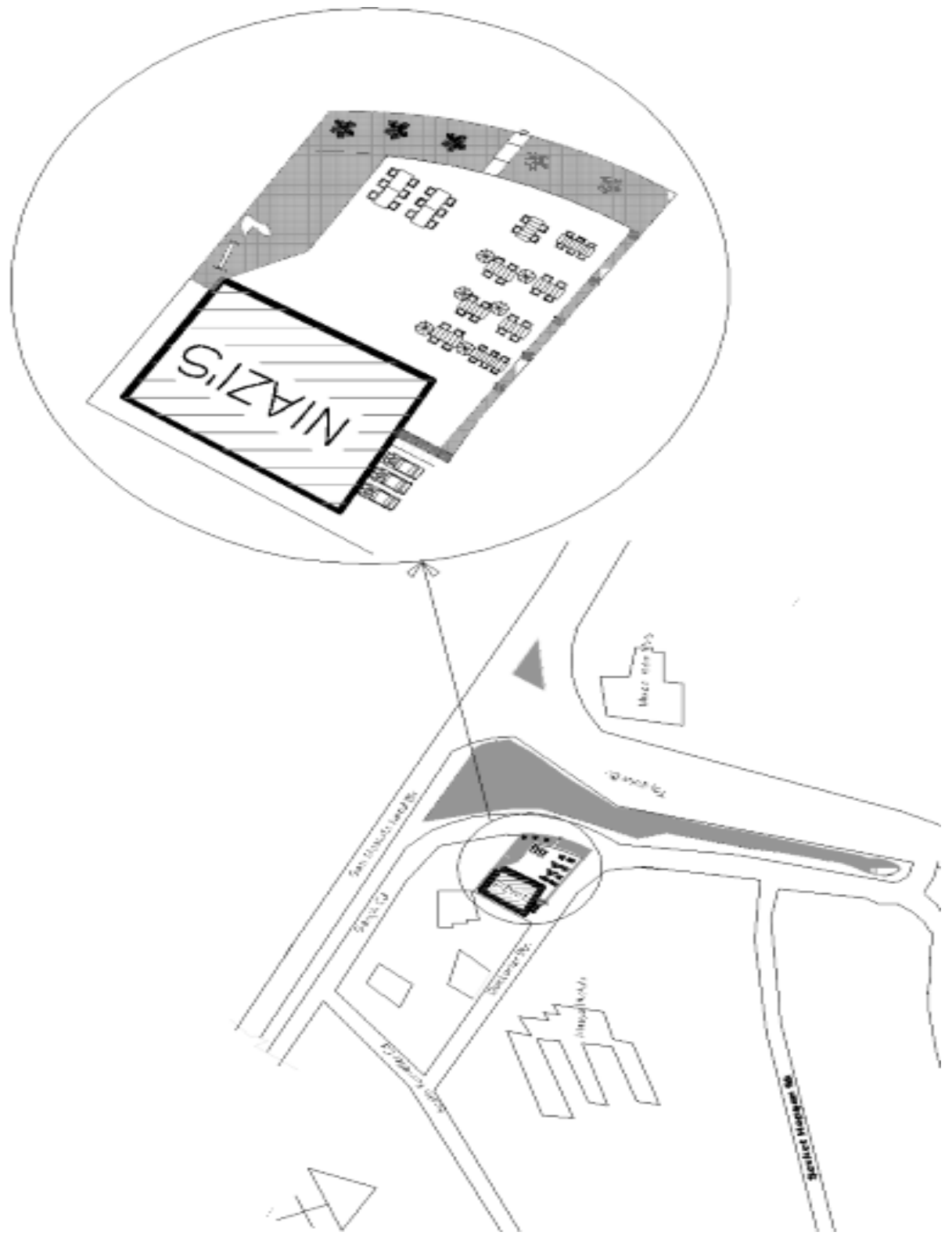

Figure 13. Site Layout of Niazi's Restaurant showing the outdoor seating area 


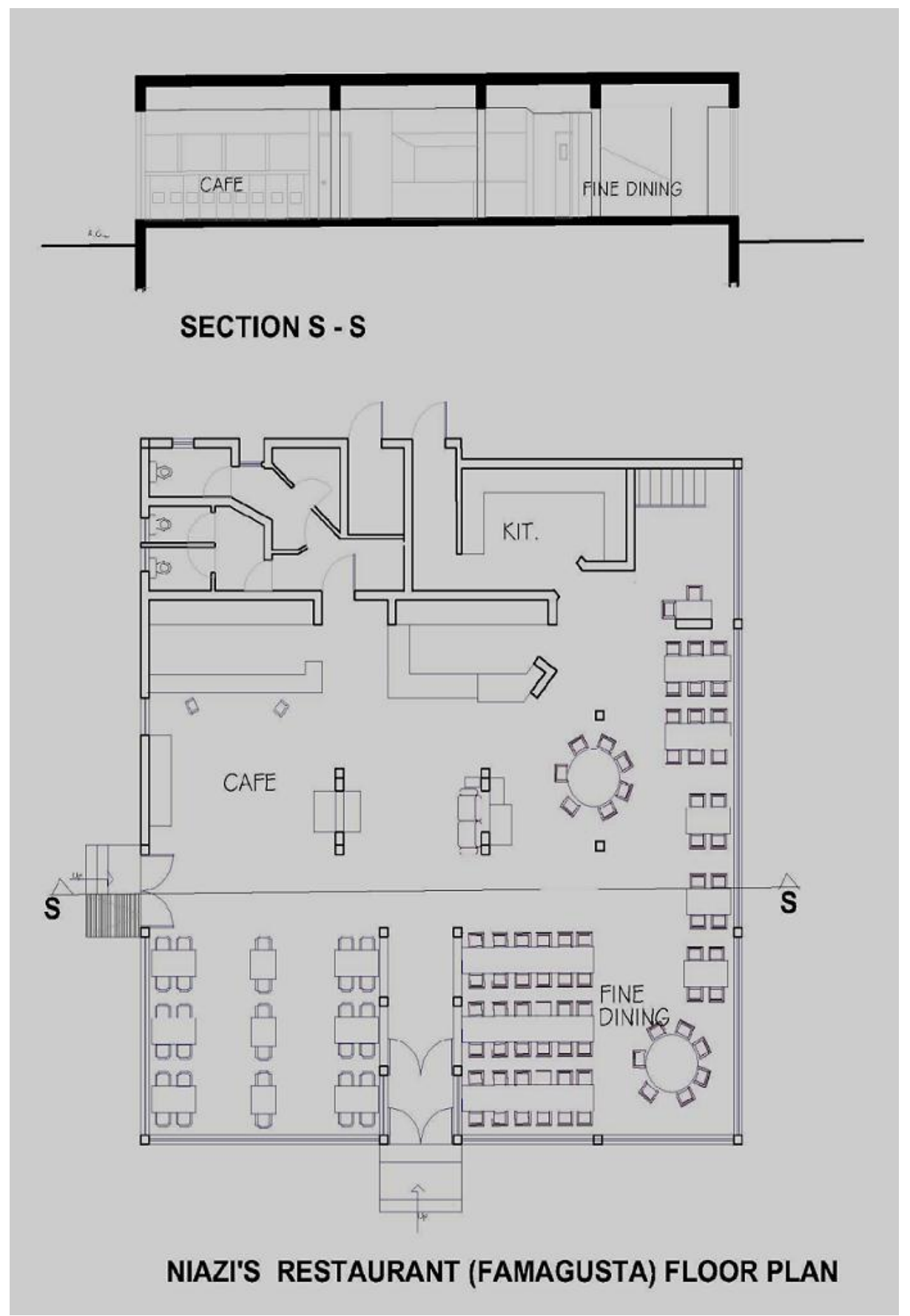

Figure 14. Floor Plan and Section of Niazi’s Restaurant

\subsubsection{Furniture Identified in Niazi's Restaurant}

The furniture types used in Niazi's Restaurant are in the category: Seats, desks and tables, and other elements, as represented in Inventory Form 2. While, the results on style, seating arrangement, and seating pattern are shown in Table 4. 
Inventory Form 2: Niazi’s Restaurant Furniture Types

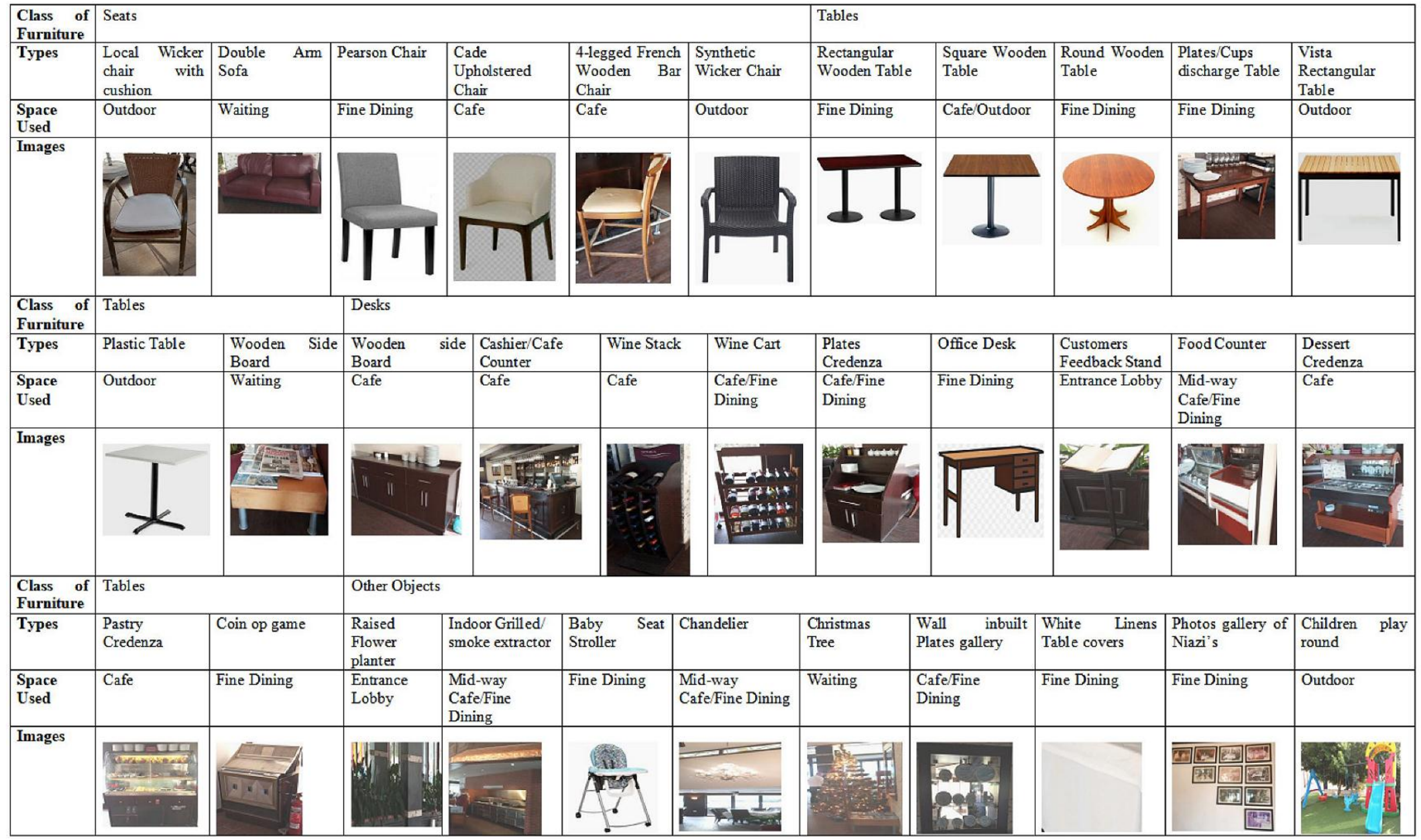


Table 4. Niazi's Restaurant furniture summary results

\begin{tabular}{|c|c|c|c|}
\hline Parameter & Fine Dining & Cafe & Outdoor \\
\hline Furniture Style & \multicolumn{3}{|c|}{ Medieval, French, Arts and crafts } \\
\hline $\begin{array}{c}\text { Seating } \\
\text { Arrangement }\end{array}$ & $\begin{array}{l}\text { - } 3 \text { sets of } 12 \text { seats to a rectangular movable } \\
\text { tables. } \\
\text { - } 2 \text { sets of } 7 \text { seats to a circular table. } \\
\text { - } 3 \text { sets of } 4 \text { seats to single rectangular table. } \\
\text { - } 1 \text { set of } 6 \text { seats to two rectangular movable } \\
\text { tables. } \\
\text { - } 1 \text { set of } 4 \text { seats to two square movable tables. }\end{array}$ & $\begin{array}{l}\text { - Two independent bar } \\
\text { seats. } \\
\text { - } 6 \text { sets of } 4 \text { seats to a } \\
\text { rectangular table. } \\
\text { - } 3 \text { sets of } 2 \text { seats to a } \\
\text { square table. }\end{array}$ & $\begin{array}{l}\text { - } 4 \text { sets of } 6 \text { seats to two movable } \\
\text { rectangular plastic tables. } \\
\text { - } 3 \text { sets of } 4 \text { seats to a rectangular } \\
\text { wooden table. } \\
\text { - } 3 \text { sets of } 4 \text { seats to two movable square } \\
\text { wooden tables. } \\
\text { - } 2 \text { sets of } 6 \text { seats to two movable } \\
\text { rectangular wooden tables. }\end{array}$ \\
\hline Seating Pattern & Perpendicular and focused staggering. & Perpendicular & Perpendicular \\
\hline
\end{tabular}

\subsection{Discussions}

Table 5. Summary difference on spatial level

\begin{tabular}{|c|c|c|}
\hline Parameter & Ginkgo Restaurant & Niazi's Restaurant \\
\hline \multicolumn{3}{|c|}{ Site Criteria } \\
\hline District & Wall City Famagusta & $\begin{array}{c}\text { Dumlupinar } \\
\text { Famagusta }\end{array}$ \\
\hline Environment & Historic center & Urban center \\
\hline Building type & $\begin{array}{l}\text { Historic stone reuse } \\
\text { building. }\end{array}$ & $\begin{array}{l}\text { Modern concrete } \\
\text { building }\end{array}$ \\
\hline $\begin{array}{c}\text { Period of } \\
\text { construction }\end{array}$ & $\begin{array}{l}\text { Around 12th-13th } \\
\text { Century }\end{array}$ & 20th Century \\
\hline \multicolumn{3}{|c|}{ Space Technical Information } \\
\hline Area & 174 square meters & 276 square meters \\
\hline $\begin{array}{l}\text { Seating capacity } \\
\text { Indoor }\end{array}$ & 61 persons & 104 persons \\
\hline $\begin{array}{c}\text { Seating capacity } \\
\text { outdoor }\end{array}$ & 42 persons & 60 persons \\
\hline $\begin{array}{c}\text { Floor material } \\
\text { texture }\end{array}$ & $\begin{array}{c}\text { Hard materials } \\
\text { (Marble tiles) }\end{array}$ & $\begin{array}{l}\text { Soft materials } \\
\text { (wood) }\end{array}$ \\
\hline Headroom & $4.8 \mathrm{~m}$ & $4.5 \mathrm{~m}$ \\
\hline
\end{tabular}

Table 6. Comparativeness on Furniture Composition

\begin{tabular}{|c|c|c|}
\hline \multicolumn{3}{|c|}{ Similarity on furniture style and seating arrangement/pattern } \\
\hline Restaurant & Ginkgo & Niazi’s \\
\hline \multicolumn{3}{|c|}{ Furniture } \\
\hline $\begin{array}{c}\text { Furniture } \\
\text { style }\end{array}$ & \multicolumn{2}{|c|}{ Arts and crafts style and French style. } \\
\hline $\begin{array}{c}\text { Seating } \\
\text { arrangement }\end{array}$ & \multicolumn{2}{|c|}{$\begin{array}{l}\text { - } 4 \text { seats to rectangular table in Fine Dining. } \\
\text { - } 6 \text { seats to two rectangular movable tables in Fine } \\
\text { Dining. } \\
\text { - } 4 \text { seats to rectangular wooden table in Cafe. } \\
\text { - } 2 \text { seats to square table. }\end{array}$} \\
\hline $\begin{array}{l}\text { Seating } \\
\text { pattern }\end{array}$ & \multicolumn{2}{|c|}{ Row seating in perpendicular pattern. } \\
\hline \multicolumn{3}{|c|}{ Differences on furniture style and seating arrangement/pattern } \\
\hline $\begin{array}{l}\text { Furniture } \\
\text { style }\end{array}$ & $\begin{array}{l}\text { Medieval style } \\
\text { and Ottoman } \\
\text { style. }\end{array}$ & Modern style \\
\hline $\begin{array}{c}\text { Seating } \\
\text { arrangement }\end{array}$ & $\begin{array}{l}-1 \text { seat to } \\
\text { circular table. } \\
-1 \text { boot with two } \\
\text { round seats to } \\
\text { square center } \\
\text { table. }\end{array}$ & $\begin{array}{l}\text { - } 7 \text { seats to circular table. } \\
\text { - } 12 \text { seats to rectangular } \\
\text { movable table. } \\
\text { - } 4 \text { seats to two square } \\
\text { movable tables. } \\
\text { - } 6 \text { seats to two movable } \\
\text { rectangular plastic table. } \\
\text { - } 4 \text { seats to rectangular } \\
\text { wooden table in Outdoor. }\end{array}$ \\
\hline $\begin{array}{l}\text { Seating } \\
\text { pattern }\end{array}$ & L-shape & Focused staggering \\
\hline
\end{tabular}

At the spatial level, the distinctiveness correlated two primary criteria: site criteria with four parameters (district, environment, building type, and period of construction), and space technical information used four parameters (area of the buildings studied, seating capacity for indoor/outdoor spaces, floor material texture, and headroom). The results on the spatial level are summarized in Table 5. Meanwhile, the similarities and differences in furniture composition consist of style, seating arrangement, and seating pattern are shown in Table 6 .

The analysis selected seven (7) indicators from Table 5-6 that are quantifiable using general analysis tools, and visualizing with Bar Chart-Figure 14, and Area Chart-Figure 15. That is rectangular tables, rectangular movable tables, square tables, area, indoor capacity, outdoor capacity, and headroom Table 7. The Charts show that the restaurant space area constitutes the primary indicator, followed by interior seating capacity, linked to space and furniture. The outdoor seating took up the third indicator of importance before other auxiliary elements. The Charts also indicate that Niazi's Restaurant operates in a flexible spatial context with more operational elements, whereas the Ginkgo Restaurant spatial context is constraining and functions with moderate features. Furthermore, at the furniture types, the comparativeness is sorted in Table 8. A conversation with the restaurant workers during the fieldwork revealed that diners prefer outdoor seating for the following reasons: Enjoy a broader view of the surrounding, receive fresh air in summers, and the primary aim of touring the city influences their tendency for outdoor seating.

Table 7. Quantifiable Indicators

\begin{tabular}{|c|c|c|c|}
\hline Item & Indicators & $\begin{array}{c}\text { Ginkgo } \\
\text { Restaurant }\end{array}$ & $\begin{array}{c}\text { Niazi's } \\
\text { Restaurant }\end{array}$ \\
\hline 1 & Rectangular Table & 14 & 9 \\
\hline 2 & Rectangular Movable Table & 4 & 6 \\
\hline 3 & Square Table & 3 & 3 \\
\hline 4 & Area & 174 & 276 \\
\hline 5 & Indoor Capacity & 61 & 104 \\
\hline 6 & Outdoor Capacity & 42 & 60 \\
\hline 7 & Headroom & 4.8 & 4.5 \\
\hline
\end{tabular}




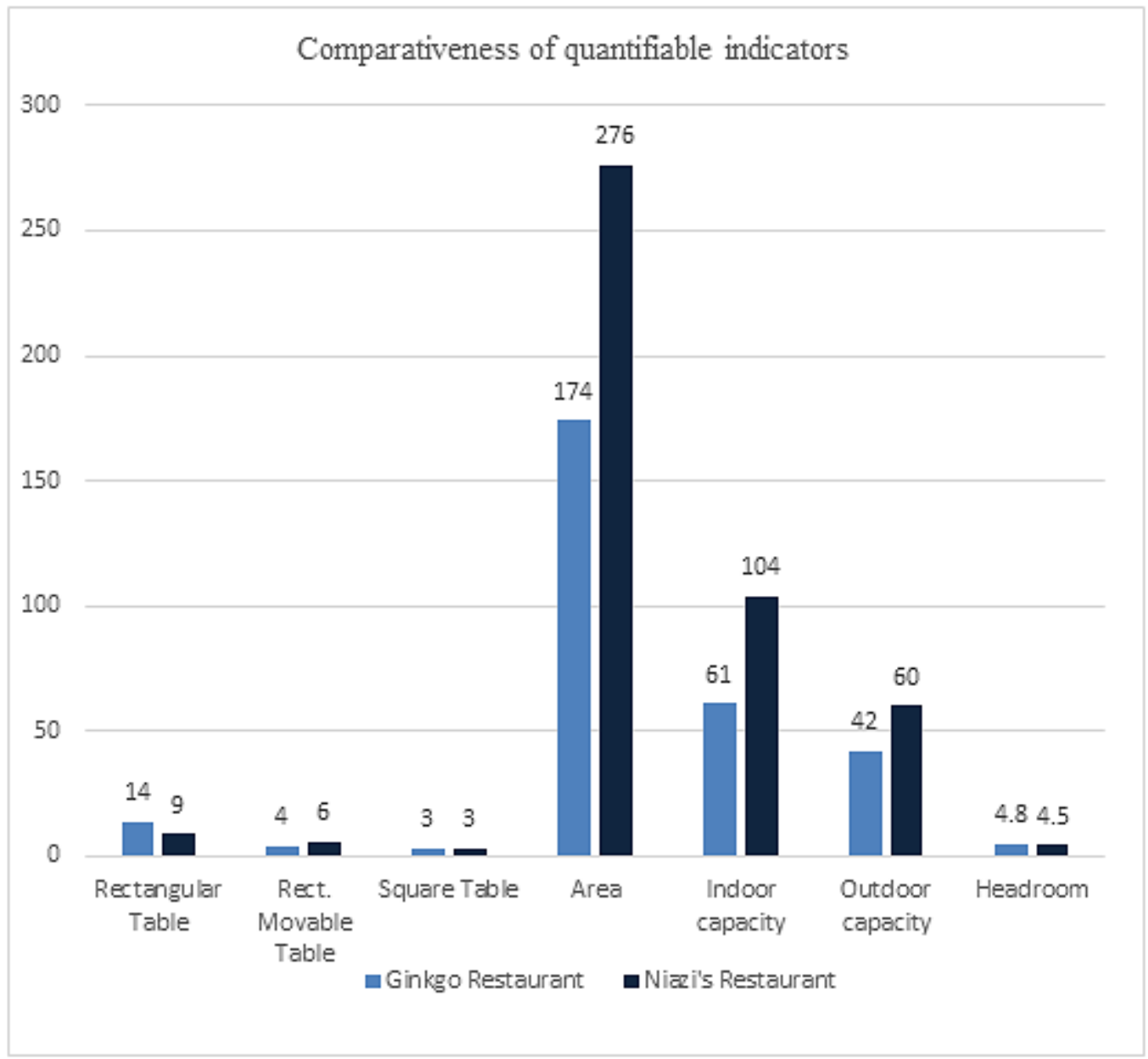

Figure 15. Comparativeness on Restaurants quantifiable indicators

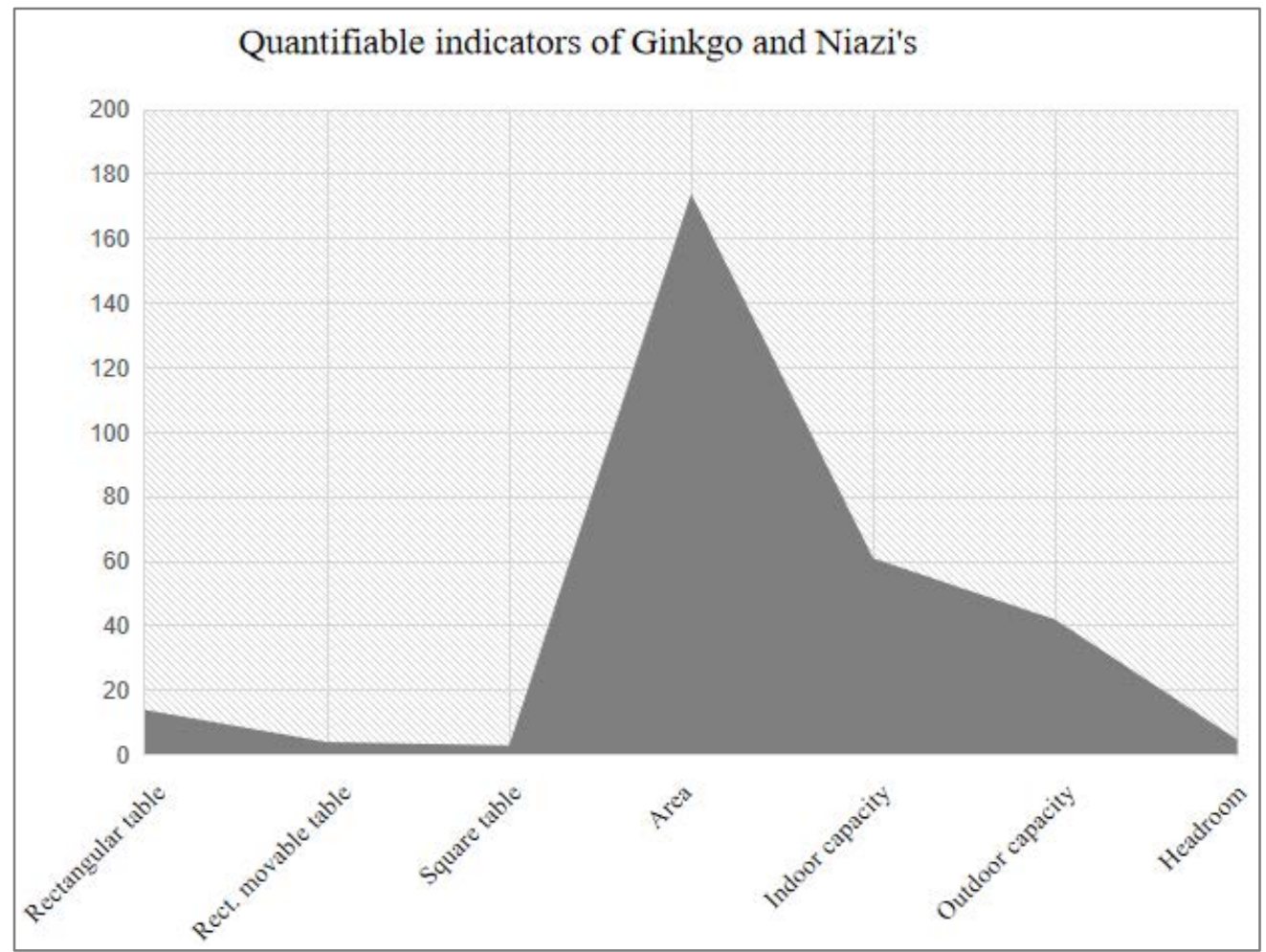

Figure 16. Comparativeness on Restaurants quantifiable indicators 
Table 8. Comparativeness on classes of Furniture types

\begin{tabular}{|c|c|c|}
\hline Element & Ginkgo Restaurant & Niazi’s Restaurant \\
\hline \multicolumn{3}{|c|}{ Class A-Furniture with all right similarity between Ginkgo and Niazi's restaurants } \\
\hline Seats & \multicolumn{2}{|c|}{ None } \\
\hline Tables & \multicolumn{2}{|c|}{ Rectangular wooden table; Square wooden table; Vista rectangular wooden table. } \\
\hline Desks & \multicolumn{2}{|c|}{ Wooden side Board; Wooden wine stack. } \\
\hline Other Objects & \multicolumn{2}{|c|}{ Baby seat stroller. } \\
\hline \multicolumn{3}{|c|}{ Class B-Furniture with partial similarity between Ginkgo and Niazi's restaurants } \\
\hline Seats & \multicolumn{2}{|c|}{$\begin{array}{c}\text { Pearsons chair but different body lining. } \\
\text { Wicker chair but with different design pattern. }\end{array}$} \\
\hline Tables & \multicolumn{2}{|c|}{$\begin{array}{l}\text { Rectangular wooden table with similar tops but different stand. } \\
\text { Round wooden table with similar tops but different stand. } \\
\text { Wooden side table with similar tops but with different stand. }\end{array}$} \\
\hline Desks & \multicolumn{2}{|c|}{ Cashier/cafe counter but different materials. } \\
\hline Other Objects & \multicolumn{2}{|c|}{ Artificial flower tree/tree planting but different species. } \\
\hline \multicolumn{3}{|c|}{ Class C-Furniture with absolute difference between Ginkgo and Niazi's restaurants } \\
\hline \multirow{3}{*}{ Seats } & $\begin{array}{l}\text { - Single King Sofa. } \\
\text { - Single arm concave Sofa. } \\
\text { - Rounded Ottoman Sofa. } \\
\text { - Gothic antique arm Couch with Nameplate. }\end{array}$ & $\begin{array}{l}\text { - Double arm Sofa. } \\
\text { - Cade upholstered chair. }\end{array}$ \\
\hline & - Straight boot with cushions & - Local made Wicker Chair with cushion. \\
\hline & $\begin{array}{l}\text { - Four legged Iron Craft Stool. } \\
\text { - Four legged Wooden Stool. }\end{array}$ & - 4 legged French Wooden Stool. \\
\hline Tables & • Wooden center Table. & - Plastic Table. \\
\hline Desks & None & $\begin{array}{l}\text { - Wine Cart. } \\
\text { - Plate Credenza } \\
\text { - Office Desk } \\
\text { - Customers feedback stand } \\
\text { - Food Counter } \\
\text { - Dessert Credenza } \\
\text { - Pastry Credenza } \\
\text { - Coin op game } \\
\end{array}$ \\
\hline Other objects & $\begin{array}{l}\text { - Local made Chalice } \\
\text { - Musical stand } \\
\text { - Antiques of pastry plate decor. } \\
\text { - Artistic/painting works. } \\
\text { - White and Red Linen table covers. }\end{array}$ & $\begin{array}{l}\text { - Grilles fire place/fumes extractor. } \\
\text { - Chandelier } \\
\text { - Wall inbuilt plates gallery } \\
\text { - Photos gallery } \\
\text { - Children Play Round } \\
\text { - White Linen table cover. }\end{array}$ \\
\hline
\end{tabular}

\section{Conclusion}

This research focused on Ginkgo and Niazi's restaurants' comparative study in Famagusta-Cyprus, contributing to restaurant design, ambiance, and operation in a growing urban setting with historical and modern contexts. The primary aim is to analyze the similarities and differences of furniture used due to cultural time intervals and restaurateur's intentions with the design concept's influence synthesized spatially and visually. The indoor and outdoor spaces' spatial relationship and interaction are studied to enhance diners' preference and affect the city's restaurant image. The study's importance is to showcase the restaurant's image to visitors, students, and other inhabitants, open possibilities for making their dining preferences compatible with their lifestyle, taste, and intentions. The literature review supports that restaurants are changing from traditional composition and operational to technological/innovative levels to cope with the age of speed and digitization. Interestingly, the analysis of this furniture contrastiveness identified three taxonomy of furniture types based on the characteristics displayed as evidence by the inventory form 1-2. Thus:

a). Class A-furniture with all right similarity.

b). Class B-furniture with partial similarity (having some parts similar, and others different mutually).

c). Class C-furniture with an absolute difference.

The two restaurants' results also show that Ginkgo and Niazi's restaurants function similarly within the commercial foodservice and full-service types in the restaurant business but at different hierarchical levels. The evaluation conducted agrees that the restaurant's ambiance's sensitivity remarked in the literature comes from the interior elements and other factors. In this context, furniture handling, spatial organization, and site layout contribute to their character's uniqueness. Social and climatological factors observations made during the 
field studies indicate that incorporating the outdoor space enlarges operations and increases customers' enjoyable level. This factor contributes to foodservice ambiance that had not been handled broadly by previous research on restaurant facilities. Notably, it is reasonable and sensitive to remark that when [47] wrote about "layout" in a restaurant, the emphasis was on a literal conceptualization conveying the arrangement of physical restaurant elements. However, the findings led to the assertion that spatiality criteria in foodservice facilities constitute the apex when ranking the tangible parameters. It is the base upon which other determinants will drive, and furniture contributes secondly before other elements in that creative profile. The authors of this paper envisage that when questionnaires and in-depth interviews are engaged in future research and the scope enlarged to different settings within Cyprus as remarked in sub-theme 2.5, it could lead to a more concrete generalization within Cyprus and helpful to similar cultural environments.

In contrast, this paper uses the term as an environmental site layout, which is practically comprehensive. The efficient and sustainable management of these elements (internal plus external) will increase the restaurant's marketability by taking selfies and posting on social media by users. It will also influence diners' behavior, especially to order more when the concept harmonies with their needs and vice versa. The harmonization mentioned becomes an additional contribution to the two determinants identified in the literature review-use of comfortable, plump sofa seats and the formation of anchored spots. More importantly, they show belonging and attachment to the space to host other affairs of their life within the restaurant environs. This kind of social, cultural link is vital for the psychological well-being of diners. Leading us to generalized the definition of furniture by taking some keywords from [48]: 'Furniture is an ergonomic product,' custodian of social, cultural, and psychological features that aid urban health and or urban life.

In general, our findings also contribute to two direct pairs of social life expression with furniture in restaurants. Furniture composition in fine dining shows a comfortable and dedicated taste for diners, fulfilling formal interface. Whereas, in Cafe and outdoor seating, the feel is stylish and smarter, performing casual dining vibes. Based on this evidence captured, the two restaurants present us with different user's preferences.

The Ginkgo shows a compact, private, and informal and awe atmosphere with a little outdoor connection. The deduction leverages the fact that it is a reuse intervention scheme and presents a traditional response to harsh weather conditions. Therefore, the restrictions on the physical fabric and spatial modifications are made to respect the integrity and authenticity of Old City Famagusta's historical context. The furniture used represents past civilizations' cultural symbols connected in
Medievalism (Greeks, Romans, Ottomans). It pays tribute to the previous cultural influences on Famagusta and Cyprus.

While Niazi's restaurant displays an atmosphere that is cozy, elaborate, formal, and warm, with active outdoor engagement assumed to emanate from the creativeness of the modern urban cultural morphology. It is also a product of brand and freedom of the restaurateur's intentions and provides technological methods of handling weather harshness. Above all, the study recommends that since cultural and environmental affiliates suggest a sustainable pillar in the architecture and operation of restaurants, restaurateurs, investors, and designers should consider such qualities when improving existing and future restaurants. Significantly as the city advances developmentally welcomes diverse visitors and students.

\section{Acknowledgements}

We are very grateful for the reviewer's comments. Thanks to the Cross River University of Technology, Nigeria, for the study leave granted to the corresponding author to undergo doctoral study at Faculty of Architecture, Near East University, North Cyprus.

\section{REFERENCES}

[1] J. Lang, "Formal Aesthetics: Perception Theory, Formal Aesthetics and the Basic Design Course," University of Pennsylvania, 1987.

[2] P. Kotler, "Atmospherics as a Marketing Tool," Journal of Retailing, Vol.49, No.4, 48-64, 1973.

[3] Y. Liu, S. Jang, "The Effects of Dining Atmospherics: An extended Medrabian-Russel model," International Journal of Hospitality Management, Vol.28, 494-503, 2009.

[4] S. Diane, "Environmental distinctions: The Discriminating Dining Environment," LesCahiers du CICLas, Vol.6, 55-77, 2005.

[5] H. Jae- Kyung, C. Kyung-Ran, "A comparative Study on Korean and Chinese Traditional Furniture based on the style of User Pattern," In the Center of Typing of Living, 1941, Online available from http://citeseerx.ist.psu.edu

[6] N. Raajpoot, "TANGSERV: A multiple item scale for measuring tangible quality in foodservice industry," Journal of Foodservice Business Research, Vol.5, 109-127, 2002.

[7] F. Joachim, M. N. Kunz, "Cafe and Restaurant Design," Te Neues Publishing Company, New York, 2005.

[8] A. Alex, "Take-out Restaurants existed in Ancient Rome and were Called Thermopolia," The Vintage News, 2017.

[9] J. Theis, "West and Wood's Introduction to Food Service," Prentice Hall, New Jersey, 2001. 
[10] N. M. Kiefer, "Economics and the Origin of the Restaurant," Cornell Hotel and Restaurant Administration Quarterly, 2002.

[11] C. Glenday, "Sobrino de Botin in Guinness World Records," Guinness World Records Limited, 2011.

[12] P. J. Atkins, "Communal Feeding in War Time: British Restaurants, 1940-1947," In Food and War in Twentieth Century Europe, Ashgate, Farnham, England, 2011.

[13] M. Symons, "The Rise of Restaurant and the Fate of Hospitality," International Journal of Contemporary Hospitality Management, Vol.25, No.2, 2013.

[14] A. Feinberg, M. Mullapudi, M. Benore, O. Page, "The Restaurant of the Future, Creating the Next-generation Customer Experience,” Deloitte Development LLC, Texas, 2016.

[15] P. Briscoe, G. Tripp, "Food and Beverages Service," Chapter 4 in M. Westcott (eds.), Introduction to Tourism and Hospitality BC, Capilano University BC Campus, Victoria BC, 2015.

[16] C. Hannah, "Five Elements of Restaurant Ambience," RESTOBIZ, 2014, Online available from https://www.resto biz.ca

[17] H. Yu, "The Psychology of Restaurant Interior Design, Part 5: Architecture," FOHLIO, 2017, Online available from https://www.fohlio.com

[18] POSist, "The Important Elements of Restaurant Interior Design and it's Impact on Customers," The Restaurant Times, Online available from https://www.posist.com

[19] C. Fiell, P. Fiell, "Designing the $21^{\text {st }}$ Century," Taschen, Köln, 2005.

[20] T. A. Gültekİn, G. V. Özkoçak, "The Importance of Anthropometry for Ergonomic Restaurant Design," antropologi, Vol.31, 61-70, 2016.

[21] A. Verma, "Modular Coordination," Design, 2017, Online available from https://www.slideshare.net

[22] E. Ukabi, "The Scale of Individual Space in Restructuring the Perception of Phobia," Scientific Research Journal, Vol.3, No.2, 16-19, 2015.

[23] J. Baker, D. Grewal, A. Parasuraman, "The influence of Store Environment on Quality Inferences and Store Image," Journal of the Academy of Marketing Science, Vol. 22, No.4, 328-339, 1994.

[24] J. S. Horng, S. F. Chou, C. H. Liu, C. Y. Tsai, "Creativity, Aesthetics and Eco-friendliness: A Physical Dining Environment Design Synthetic Assessment Model of Innovative Restaurants," Tourism Management, Vol.36, $15-25$,

2013 , http://dx.doi.org/10.1016/j.tourman.2012.11.002

[25] E. T. Hall, "The Hidden Dimension," Doubleday \& Company, Garden City,1966.

[26] Q. Pickard (eds.), “The Architects' Handbook," Blackwell Science Ltd, Garsington, 2002.

[27] A. Aalto, "Architecture and Furniture," The Museum of Modern Art, New York, 1938.
[28] M. Peterson, "Incorporating Customer Perspectives in Architectural Design of Servicescapes," Advances in Consumer Research, Vol.30, 208-210, 2003.

[29] P. Wardono, H. Hibino, S. Koyama, "Effects of Restaurant Interior Elements on Social Dining Behavior," cE-Bc, FSPU, UiTM, 2010.

[30] K. M. Rutkin, "User Preference of Interior Design Elements in Hotel Lobby Spaces," Master Thesis, University of Florida, 2005.

[31] A. Mehrabian, S. G. Diamond, "Seating Arrangement and Conversation," Sociometry, Vol.34, No.2, 281-289, 1971.

[32] M. L. Patterson, C. E. Kelly, B. A. Kondracki, L. J. Wulf, "Effects of Seating Arrangement on Small-Group Behavior," Social Psychology Quarterly, Vol.42, No.20, 180-85, 1979.

[33] J. Archea, "The Place of Architectural Factors in Behavioral Theories of Privacy," Journal of Social Issues, Vol.33, No.3, 116-137, 1977.

[34] S. K. A. Robson, "A Review of Psychological and Cultural Effects on Seating Behavior and Their Application to Foodservice Settings," Journal of Foodservice Business Research, Vol.5, No. 2, 89-107, 2002.

[35] S. E. Kimes, S. K. A. Robson, "The Impact of Restaurant Table Characteristics on Meal Duration and Spending," Cornell University, Cornell Hotel and Restaurant Administration Quarterly, Vol.45, No.4, 333-346, 2004.

[36] S. R. Sonyel, "The Destruction of a Republic and its aftermath," CYREP, Lefkosia, 2003.

[37] K. Tofallis, "A History of Cyprus: From the Ancient Times to the Present," The Greek Institute, London, 2002.

[38] N. Doratli, S. Hoskara, N. Zafer, A. Ozgürün, "The Walled City of Famagusta (Gazimagusa): An Opportunity for Planned Transformation," Proceedings of "The Planned City?", ISUF International Conference, Vol. 2, 443-448, 2003.

[39] K. Kusbiantoro, P. Hee, "The Adaptation of Korean Dining Culture in Korean Restaurant at Bandung (Case Study: Korean House, Han Kook Gwan and Mujigae)," The International Journal of Social Sciences, Vol.32, No.1, 046-053, 2015.

[40] A. Langdale, "At the Edge of Empire: Venetian Architecture in Famagusta, Cyprus," Viator, Vol.41, No.1, 155-198, 2010

[41] S. Panteli, "A new History of Cyprus: From Earliest Times to the Present Day," East-West Publishers, London and Haque, 1984.

[42] N. Yildiz, "Ottoman Period in Cyprus: A Glance at Turkish Architecture," New Cyprus, 22-27, 1992.

[43] S. Söderholm, "Gingko Café and Restaurant in Famagusta," News Cyprus Magazine, 2014. Online available from http://www.newcyprusmagazine.com

[44] "Ginkgo International in Famagusta (Gazimağusa)," Online available from https://www.lonelyplanet.com

[45] "Niazi's since 1949," Online available from https://www.niazis.com 
[46] M. Eriksson, "Niazi's-The Restaurant that Created full Kebab,” News Cyprus Magazine, 2017, Online available from http://www.newcyprusmagazine.com

[47] D. Tuzunkan, A. Albayrak, "The Importance of Restaurant Physical Environment For Turkish Customers," Journal of
Tourism Research \& Hospitality, Vol.5, No.1, 2-8, 2016.

[48] D. B. Tuncel, H. Z. Kayan, "The Design of Flexible Furniture for the New Generation Offices," Civil Engineering and Architecture, Vol.6, No.2, 78-87, 2018, DOI: $10.13189 /$ cea.2018.060205 